\title{
Adhesion of Escherichia Coli to Nanostructured Surfaces and the Role of Type 1 Fimbriae
}

\author{
Pawel Kallas ${ }^{1}\left(\mathbb{D}\right.$, Håvard J Haugen ${ }^{1, * \mathbb{C}}$, Nikolaj Gadegaard ${ }^{2}$, John Stormonth-Darling ${ }^{2}$, \\ Mats Hulander ${ }^{3}$, Martin Andersson ${ }^{3}$ and Håkon Valen ${ }^{4}$ \\ 1 Department of Biomaterials, Institute of Clinical Dentistry, University of Oslo, 0455 Oslo, Norway; \\ pawel.kallas@odont.uio.no \\ 2 School of Engineering, University of Glasgow, G12 8QQ Glasgow, UK; \\ Nikolaj.Gadegaard@glasgow.ac.uk (N.G.); John.Stormonth-Darling@glasgow.ac.uk (J.S.D.) \\ 3 Department of Chemistry and Chemical Engineering, Chalmers University of Technology, \\ 41258 Göteborg, Sweden; mats.hulander@chalmers.se (M.H.); martin.andersson@chalmers.se (M.A.) \\ 4 Nordic Institute of Dental Materials, 0855 Oslo, Norway; hakon.valen@niom.no \\ * Correspondence: h.j.haugen@odont.uio.no; Tel.: +47-2285-2170
}

Received: 9 October 2020; Accepted: 10 November 2020; Published: 12 November 2020

\begin{abstract}
Bacterial fimbriae are an important virulence factor mediating adhesion to both biotic and abiotic surfaces and facilitating biofilm formation. The expression of type 1 fimbriae of Escherichia coli is a key virulence factor for urinary tract infections and catheter-associated urinary tract infections, which represent the most common nosocomial infections. New strategies to reduce adhesion of bacteria to surfaces is therefore warranted. The aim of the present study was to investigate how surfaces with different nanotopography-influenced fimbriae-mediated adhesion. Surfaces with three different nanopattern surface coverages made in polycarbonate were fabricated by injection molding from electron beam lithography nanopatterned templates. The surfaces were constructed with features of approximately $40 \mathrm{~nm}$ width and $25 \mathrm{~nm}$ height with $100 \mathrm{~nm}, 250 \mathrm{~nm}$, and $500 \mathrm{~nm}$ interspace distance, respectively. The role of fimbriae type 1-mediated adhesion was investigated using the E. coli wild type BW25113 and $\triangle$ fimA (with a knockout of major pilus protein FimA) and $\Delta$ fimH (with a knockout of minor protein FimH) mutants. For the surfaces with nanotopography, all strains adhered least to areas with the largest interpillar distance $(500 \mathrm{~nm})$. For the E. coli wild type, no difference in adhesion between surfaces without pillars and the largest interpillar distance was observed. For the deletion mutants, increased adhesion was observed for surfaces without pillars compared to surfaces with the largest interpillar distance. The presence of a fully functional type 1 fimbria decreased the bacterial adhesion to the nanopatterned surfaces in comparison to the mutants.
\end{abstract}

Keywords: nanostructured surface; injection molding; anti-adhesive; E. coli; fimbriae; anti-bacterial; biomaterial-associated infections (BAI)

\section{Introduction}

Bacterial adhesion, colonization, and biofilm formation on medical devices are responsible for a large proportions of nosocomial infections, and biomaterial-associated infections are common post-operative [1-4]. Catheter-associated urinary tract infections (CAUTI) are the most common hospital acquired bacterial infection and are associated with increased mortality and morbidity [5]. The gram negative bacterium Escherichia coli (E. coli) is the most frequent cause of CAUTIs [6].

E. coli is naturally found in the intestinal flora of humans and animals [7] and includes both non-pathogenic and pathogenic strains [8-10]. Some E. coli strains express type 1 fimbria, a bacterial adhesion that has been reported to facilitate adhesion to other bacteria, host cells, and surfaces of medical 
devices [11]. Type 1 fimbria have a polymeric protein structure, made of FimA, FimF, FimG, and FimH monomers, with a tubular structure of $7 \mathrm{~nm}$ in width and 1-2 $\mu \mathrm{m}$ in length [12-14]. Expression of fimbriae has been reported to be an important virulence factor for uropathogenic $E$. coli, important for biofilm formation on abiotic surfaces [15]. E. coli expressing type 1 fimbriae was observed to contribute to catheter-associated urinary tract infections in a dynamic catheterized bladder model [16]. The biofilm may act as a natural barrier, protecting bacteria from antimicrobial treatment [17], and biofilms are associated with reduced susceptibility towards antimicrobial treatment [18].

Fimbrial adhesins can also be present in other Gram-negative species like Serratia marcescens or Klebsiella pneumoniae, where they a play crucial role in biofilm formation $[19,20]$. Fimbria is an important virulence factor for urinary tract infections [16], where E. coli has been reported to be the most prevalent pathogen [21-25], and the presence of fimbriae type 1 enhances the survival of $E$. coli in the urinary tract [26].

Finding new solutions in the fight against bacteria and, therefore, the need to develop medical devices that prevent adhesion of bacteria is highly desired. Controlling bacterial colonization can be done by modifying surface properties of medical devices, such as adhesion properties and coatings, surface roughness, and chemistry $[27,28]$. Changing surface topography, by altering the surface roughness and its complexity, can affect bacterial adhesion and therefore lower the risk of a potential infection [29-33]. Previous studies have shown that bacterial adhesion can also be influenced by the presence of metallic nanoparticles that show antimicrobial properties, such as such as silver (Ag), gold $(\mathrm{Au})$, and zinc oxide $(\mathrm{ZnO})$ [34]. Another type of nanoparticles that presents antibacterial and biocompatible features is silicon nanoparticles [35-38].

An important obstacle for nanomaterials is the step from scientific idea to a product on the market. Manufacturers need to have high scale, high quality production, and preservation of the desired properties of the nanomaterials [39]. Electron beam lithography (EBL) is a production technique that may enable high production with reproducible quality of materials with surface modifications in the nano-range [40].

The aim of our study was to investigate whether surfaces with different nanoscale topographies affected fimbriae-mediated adhesion of E. coli. The hypothesis was that presence of fimbriae has an effect on bacterial attachment to nanostructured surfaces. Electron beam lithography was used to produce controlled nanoscale surface topographies on a template for fabricating injection molded polycarbonate substrates as a model system with varying surface coverages. The higher the interspace distance between nanopillars, the lower the contact area between bacteria and nanopillars. If were to increase that distance, the individual bacteria would only have contact with a few pillars. Therefore, we decided to fabricate surfaces with interspace distances between nanopillars smaller than the actual size of the tested bacteria, namely 100, 250, and $500 \mathrm{~nm}$.

\section{Materials and Methods}

\subsection{Preparation of Nanostructured Surfaces}

Nanostructured polymer surfaces were prepared by injection molding of patterns mastered by electron beam lithography on silicon masters. Silicon samples were solvent and oxygen plasma cleaned, dehydrated, and oxygen plasma treated again (this time for adhesion promotion) before immediately being spun on hydrogen silsesquioxane (HSQ) resist (FOx 12) at a thickness corresponding to the desired nanofeature height. Patterns were written in a Vistec VB6 UHR EWF EBL tool (Vistec Electron Beam GmbH, Jena, Germany) operating at $100 \mathrm{kV}$ and developed in $25 \%$ tetramethylammonium hydroxide (TMAH) solution at $23^{\circ} \mathrm{C}$ followed by rinsing in water and isopropyl alcohol (IPA). As it was not possible to spin HSQ films thinner than $\sim 40 \mathrm{~nm}$, the $20 \mathrm{~nm}$ features had to be defined by dry etching with the HSQ pattern, and the mask was subsequently removed by hydrofluoric acid (HF). Dry etching was performed in an STS ICP silicon etch tool using a mixed process and always 
preceded by a dilute HF dip (2000:1, 48\% HF:RO water, by vol.) to prevent micromasking by native oxide. All chemicals were provided by Sigma-Aldrich, Saint-Louis, MO, USA.

Nanopatterns were then replicated using an UV-based nanoimprint lithography (UV-NIL) (EV Group, Sankt Florian am Inn, Austria) into the working stamp material. Silicon masters were first spin coated with the EVG anti-stick material, followed immediately by the working stamp material, which was UV cured against the master onto a carried foil by way of the NIL tool's standard working stamp recipe. UV-NIL was performed using a custom-built pocket imprinter. Each working stamp replica was laser cut to the appropriate dimensions of the injection molding tool, as described in [41].

Injection molding was performed in an Engel Victory 28 hydraulic injection molding machine (Engel Austria GmbH, Schwertberg, Austria) to produce multiple polystyrene samples for biological experiments. Each surface consisted of $9 \times 4$ repetitions of pattern divided into three sections (total size $1 \times 3 \mathrm{~mm}$ ) with different surface coverages, namely $2.5,3.5$, and $20 \%$. The total number of surface coverages produced was $n=972$, although due to production process, some gradients were not included in the image analysis. Therefore, the total number of nanostructured surfaces with different coverages measured was 191.

\subsection{Surface Characterization}

The heights of the pillars were characterized with an atomic force microscope (Veeco Dimension 3100, Santa Barbara, CA, USA). AFM images were processed using Gwyddion software version 2.51 (Free Software Foundation, Boston, MA, USA) to obtain depth data. Water contact angles measurements were performed on the experimental surfaces using a model 100-00-230 NRL contact angle goniometer (Ramé-Hart Inc. Mountain Lakes, NJ, USA) in order to assess surface wettability. A small $5 \mu \mathrm{L}$ MQ water droplet was applied on the surface. The average contact angle was measured based on seven measurements at $30 \mathrm{~s}$ time point.

\subsection{Bacterial Preparation and Growth}

E. coli strains BW25113 7636 (later referred as E. coli-WT), JW4277-1 11065 ( $\Delta$ fimA, E. coli- $\Delta$ fimA), and JW4283-3 11068 ( $\Delta$ fimH, E. coli- $\Delta$ fimH) (The Coli Genetic Stock Center, Yale University, New Haven, $\mathrm{CT}$, USA) were grown in tryptic soy broth (TSB, Sigma-Aldrich, Oslo, Norway) medium overnight at $37^{\circ} \mathrm{C}$ in centrifuge tubes and $5 \% \mathrm{CO}_{2}$ atmosphere. E. coli- $\Delta$ fim $A$ and E. coli- $\Delta$ fimH are mutant strains that lack the fimA and fimH genes, respectively. Such genes play a role in the production of fimbriae, and their parent is the E. coli-WT strain that has type 1 fimbriae [42]. The overnight culture was diluted 10 times the morning after and left to grow again in the same conditions until optical density reached $\mathrm{OD}_{600}=1$ (Thermo Scientific Spectronic 200E, Waltham, MA, USA). After that, samples were centrifuged at $5000 \mathrm{rpm}$ at $21^{\circ} \mathrm{C}$ to obtain a pellet. Medium residues were discarded and exchanged for PBS in order to obtain the same $\mathrm{OD}_{600}=1$. Afterwards, the pellet, in phosphate buffered saline (PBS, Lonza, Verviers, Belgium), was shaken, and the obtained solution was used later for injection. Average colony-forming units (CFUs) were measured by culturing bacteria overnight on TSB agar plates (overnight at $37^{\circ} \mathrm{C}$ and $5 \% \mathrm{CO}_{2}$ atmosphere). There was no observed significant difference in the number of colony forming units $(\mathrm{CFU})$ at $\mathrm{OD}_{600}=1$ between the strains investigated.

\subsection{Bacterial Adhesion}

After placing the sample in the flow chamber, the system was flushed with distilled water for about $1 \mathrm{~min}$ at a constant flow of $20 \mathrm{~mL} / \mathrm{min}$ to remove any air bubbles trapped in the system. Then, $10 \mathrm{~mL}$ of bacteria in PBS was injected in the system manually using a syringe. The valves were then closed, and bacteria were let to adhere under static conditions for $5 \mathrm{~min}$ at room temperature. This procedure was followed by manually injecting $10 \mathrm{~mL}$ of $0.01 \%$ acridine orange (AO) to stain the cells for later viewing with fluorescence microscopy. After $3 \mathrm{~min}$ staining, valves were open again and sample was flushed for $5 \mathrm{~min}$ with distilled water at the same flow rate as before $(20 \mathrm{~mL} / \mathrm{min})$. The setup 
is presented in Figure 1. Each strain was tested three times, and the total number of tested surface coverages was 191.

(a)

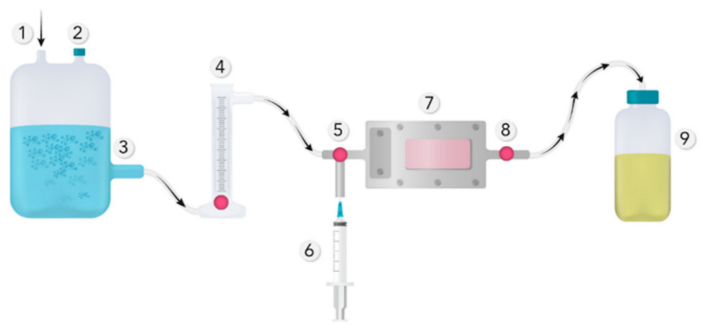

(b)

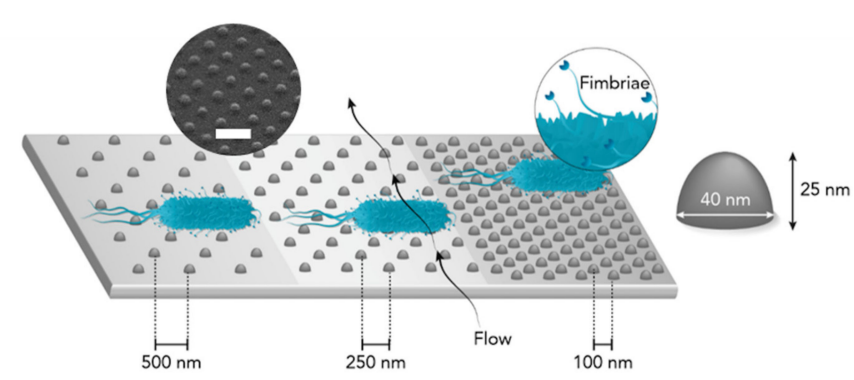

Figure 1. Flow chamber setup (a): 1-air supply, 2-air outlet, 3-distilled water tank, 4-flow meter, 5-right valve, 6-syringe input, 7-flow chamber with nanopatterned sample $(n=191)$, 8 -left valve, 9-waste container; (b) graphical overview of tested surface (not in scale) with pillar height and width. Blue is bacteria. Arrows show direction of the flow. Interspace between pillars: 1-100 nm, 2-250 nm, 3-500 nm. Scanning electron microscope (SEM) image shows nanopattern ( $30^{\circ}$ tilt) with scale bar $=200 \mathrm{~nm}$.

\subsection{Fluorescence Microscopy}

For the counting of bacteria on the surfaces, the closed flow chamber, including glass cover, was transferred to a fluorescence light microscope (Olympus BX51, Olympus Optical, Tokyo, Japan). Pictures were taken at magnification of $90 \times$ by using a $10 \times$ magnification objective with U-MNB2 filter (excitation BP 470-490 nm and emission LP $520 \mathrm{~nm}$ ), and one image was taken for each surface coverage for all replicas $(n=191)$.

\subsection{Scanning Electron Microscopy}

Samples were stored overnight in 2.5\% glutaraldehyde buffered with $0.1 \mathrm{M}$ Sørensen phosphate buffer, and afterwards were flushed with ethanol and PBS [43]. A field emission scanning electron microscope (SEM) was used to characterize the surfaces (Hitachi S-4800, Toyko, Japan). A thin layer of platinum ( $3 \mathrm{~nm}$ ) was sputtered onto surfaces (Cressington 308R Coating System, Watford, UK), prior to SEM imaging. Pictures were taken at a magnification of $15 \mathrm{k}$ with the working distance (WD) set at $1.5 \mathrm{~mm}$ and acceleration voltage of $2.0 \mathrm{kV}$. The tilted image showing the nanopattern was taken at a magnification of $20 \mathrm{k}$ with the working distance set at $13.3 \mathrm{~mm}$, acceleration voltage of $10 \mathrm{kV}$, and tilt set at $30^{\circ}$.

\subsection{ImageJ Analysis}

Image analysis was performed using ImageJ software version 1.53a (NIH, Bethesda, MD, USA). To calculate the coverage of the nanopattern, each picture was set to 8-bit, and the level of threshold was set to obtain a visible contrast between nanopattern and surface, which were later measured using the "Analyze particles" plugin. To calculate the number of bacteria, we used an already established macro plugin [44], which allowed us to crop the original image in order to avoid artefacts from vignetting 
during the automated counting. The number of bacteria was then counted using the "find maxima" feature in the program, using a noise threshold of 12.

\subsection{Statistical Analysis}

Statistical analysis was performed using GraphPad Prism version 6.07 (GraphPad software, La Jolla, CA, USA). The effect of the different surface coverages for adhesion of the individual bacteria was analyzed using one-way ANOVA with repeated measurements followed by the Tukey's multiple comparisons test. For analysis of the main effect of bacteria and surface coverage, a two-way ANOVA with repeated measurements (two factors in the experiment: surface coverage and bacteria strain) was performed followed by the Tukey's multiple comparisons test for the simple effects within each column, and each bacterial strain compared to each other for each surface coverage was performed. For a subset of surfaces $(n=10)$ Students T-test was used to analyze differences in adhesion between surfaces without pillars compared to surfaces with the largest interpillar distance. Results were considered significant with a p-value $\leq 0.05$. SPSS, version 25 (IBM Corp., New York, NY, USA), was used for calculating marginal means of bacteria number for all tested strains with significance at $p$-value $\leq 0.05$. Total number of analyzed surface coverages was $n=191$. Power analysis was conducted using $G^{*}$ Power version 3.1 (The G*Power Team, Düsseldorf, Germany). The effect size and total sample size were calculated with an alpha probability of 0.05 and power of $0.95[45,46]$.

\section{Results}

\subsection{Surface Characteristics}

Surfaces with injection molded $40 \mathrm{~nm}$ diameter features in polycarbonate were fabricated. Each pattern was divided into three sections with different surface coverages. The AFM measurements provided the interspace $(100,250$, and $500 \mathrm{~nm})$, pillar diameter of $40 \mathrm{~nm}$, and pillar height of $25 \pm 5 \mathrm{~nm}$ (Figure 2).
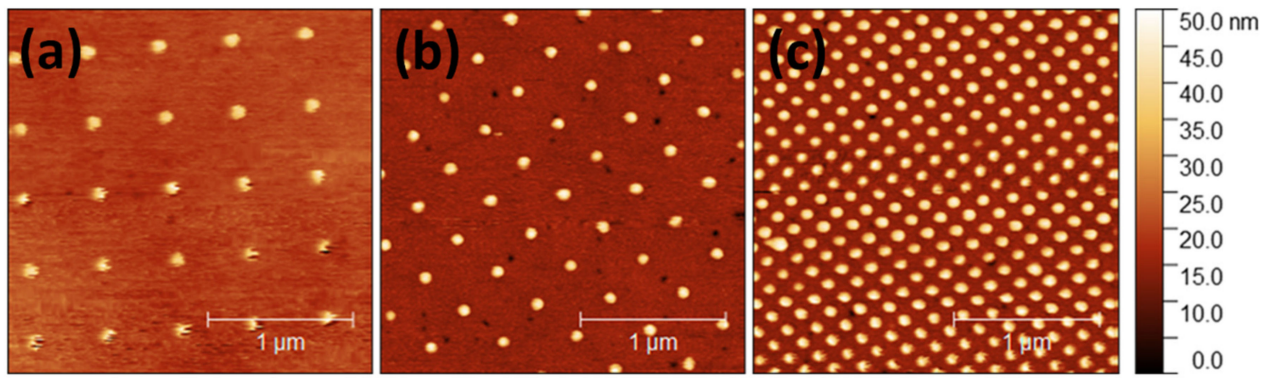

SURFACE COVERAGE

\begin{tabular}{|c|c|c|c|c|c|}
\hline Surface & $\begin{array}{c}\text { Coverage } \\
(\%)\end{array}$ & $\begin{array}{l}\text { Interspace } \\
\quad(\mathrm{nm})\end{array}$ & $\begin{array}{l}\text { Diameter } \\
(\mathrm{nm})\end{array}$ & $\begin{array}{l}\text { Height } \\
(\mathrm{nm})\end{array}$ & $\begin{array}{c}\text { Contact angle } \\
\left({ }^{\circ}\right)\end{array}$ \\
\hline (a) - Low Coverage & 2.5 & 500 & & & \\
\hline (b) - Medium Coverage & 3.5 & 250 & 40 & $25 \pm 5$ & $67 \pm 4$ \\
\hline (c) - High Coverage & 20 & 100 & & & \\
\hline
\end{tabular}

Figure 2. AFM images of surfaces with scale presented height (nm): (a) low coverage (LC), (b) medium coverage (MC), (c) high coverage (HC), and table below showing the characterization of the nanopillars with interspace, diameter, and height $(n=5)$.

Wettability analysis along the surface showed that the characterized contact angle was smaller than $90^{\circ}$ (after $30 \mathrm{~s}$ of measurement, an average contact angle was $67^{\circ}$ ), which means that surfaces used in our study were hydrophilic. Due to the small size of the nanopatterns $(1 \times 3 \mathrm{~mm})$, we were limited to individual measurements of each nanopattern and present here only the overall surface contact angle. 


\subsection{Bacterial Adhesion}

Fluorescent microscopy images of adhered bacteria were used to quantify bacterial adhesion to the surfaces. An example of low coverage (Figure 3a), medium coverage (Figure 3b), and high coverage (Figure 3c) under fluorescence microscope is presented. Based on the power analysis, the calculated effect size was 0.29 . Therefore, the calculated sample size was 186 . In our study we used 191 surface coverages, which is higher than the calculated one. For each of the E. coli-WT, E. coli- $\Delta$ fimA, and $E$. coli- $\Delta$ fim $H$, increased adhesion with increasing surface coverage of nanopatterns was found (Figure 4a). The two-way ANOVA showed a significant main effect for both surface area coverage and the presence of type 1 fimbriae or not on adhesion. There was a significant increased adhesion for the mutants not expressing type 1 fimbriae compared to the wild type for each of the different surface coverages (low coverage, medium coverage, high coverage, Figure $4 \mathrm{~b}$ ). In order to compare an overall bacteria adhesion to different nanopattern surface coverages, the marginal means for all tested bacteria were calculated (Figure 4a). A graphical presentation of bacterial behavior on tested surface coverages is presented on Figure $4 c$.
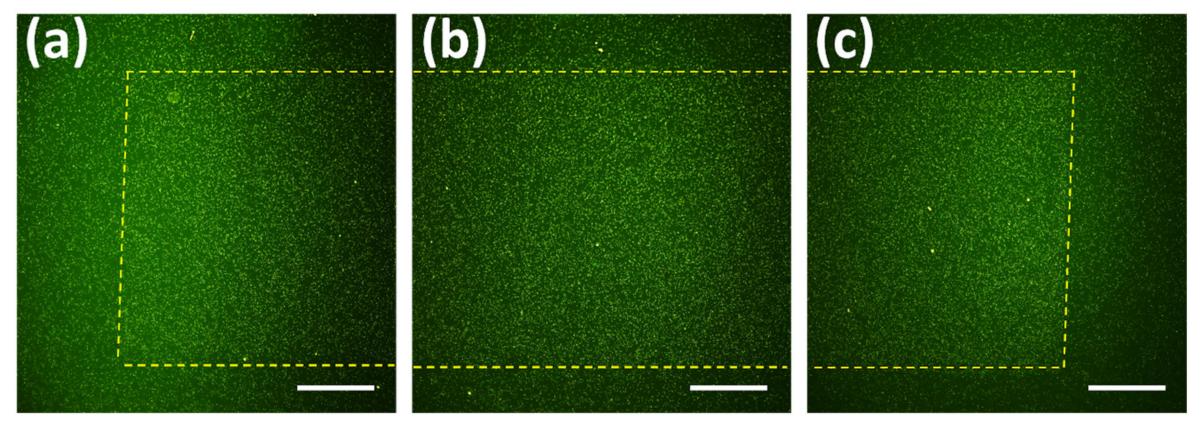

Figure 3. Fluorescent images of E. coli-WT after $5 \mathrm{~min}$ adhesion to different surface coverages at $10 \times$ magnification: (a) Low Coverage, (b) Medium Coverage, (c) High Coverage. The yellow dash marks the edges of the nanopattern. Green is bacteria. Scale bars $=250 \mu \mathrm{m}$.

(a)

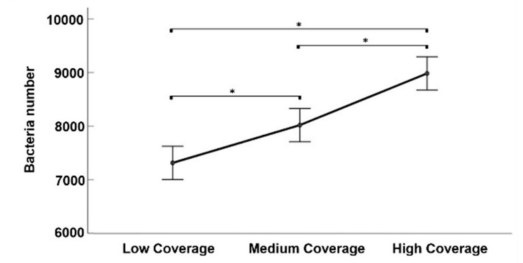

(b)

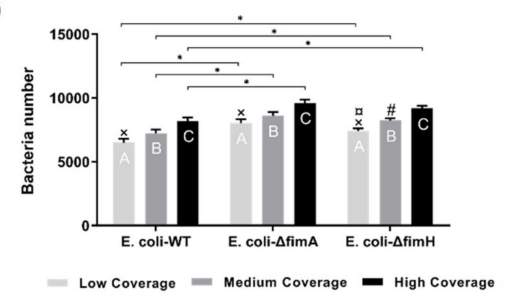

(c)
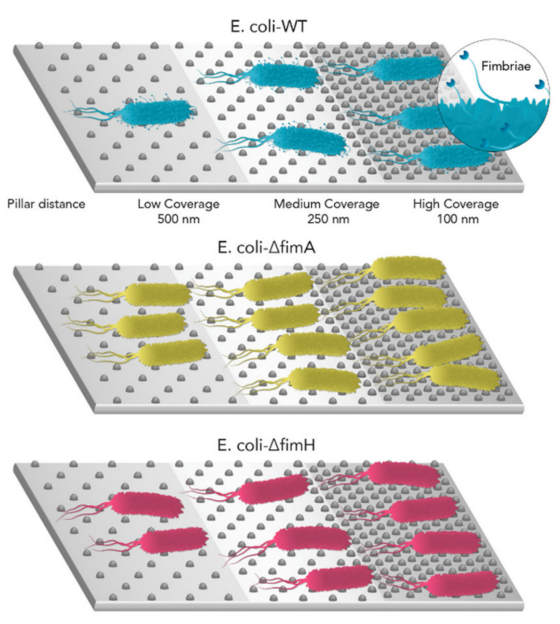

Figure 4. Bacteria adhesion to different surface coverages: (a) Bacteria number (calculated marginal means) for all tested strains. Significant at $*$-value $<0.05$. Median values with error bars represent the $95 \%$ confidence interval $(n=191, * p<0.05)$; (b) average bacteria number to different surface coverages with the standard error of the mean. Comparison within tested strains (significant at $p$-value $<0.05$, $n=191$ ): $\times$ low coverage $v$ s. medium coverage, \# low coverage $v s$. high coverage, a medium coverage vs. high coverage; (c) graphical presentation of tested strains attaching to different surface coverages.

Bacteria were observed to adhere to the nanopattern surfaces without losing their physiological morphology, keeping the characteristic rod shapes (Figure 5). No damaged bacteria cells were spotted 
during our study. The number of nanopillars in contact with one bacterium for the different surface coverages was calculated. Depending on the position of a single bacterium, the number of contact points for low coverage surfaces were 1-4 pillars, for medium coverage surfaces 8-10 pillars, and for high coverage surfaces approximately 45 pillars.
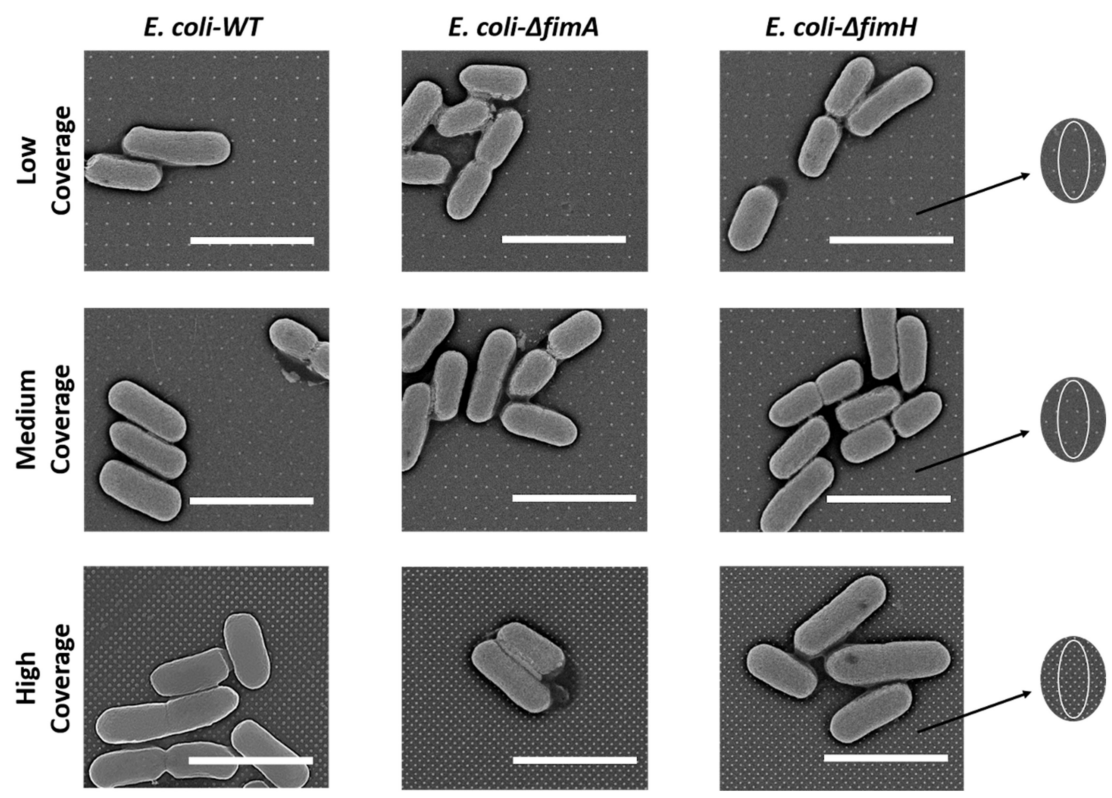

Figure 5. SEM images of tested bacteria. Fimbriae were not visible in all cases. Black arrows point at the theoretical position of bacteria (white oval) on the nanopattern. Scale bars $=2 \mu \mathrm{m}$.

The effect of fimbriae on adhesion was observed by calculating and comparing marginal means (Figure 6a), where higher attachment was observed for E. coli without fimbriae. To analyze the effect of the presence of pillars, adhesion to areas without pillars, that is, smooth surfaces, was compared to areas with low coverage. Increased adhesion for the fim $A$ and fim $H$ mutants to the low coverage surfaces was observed compared to areas without pillars, whereas no difference was observed for the E. coli-WT (Figure 6b).

(a)

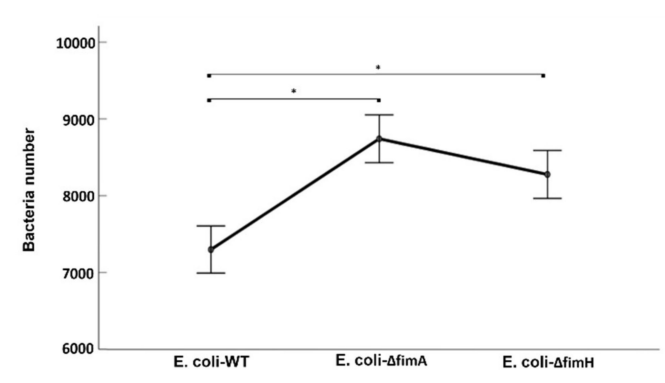

(b)
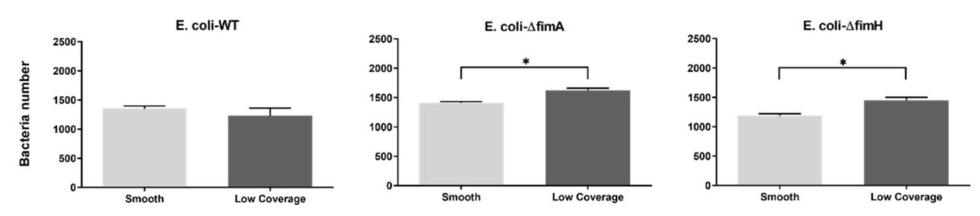

Figure 6. Effect of fimbriae on adhesion for all tested E. coli strains. (a) Bacteria number (calculated marginal means) significant at * $p$-value $<0.05$. Median values with error bars represent the $95 \%$ confidence interval $(n=191, * p<0.05)$. (b) Comparison within tested strains between smooth and low coverage. Average bacteria number to different surface coverages with the standard error of the mean. Significant at * $p$-value $<0.05, n=10$. 


\section{Discussion}

Our work focused on investigating how nanopatterned surfaces affected the adhesion of E. coli and whether presence of fimbria would affect adhesion. Using a replication-based fabrication process, which combines an electron beam lithography and injection molding, we were able to create and examine a large number of surfaces with identical patterns and features. This process, as described in the previous work of Stormonth-Darling et al. [47], realizes the possibility of manufacturing almost any desired pattern and is a method considered to be a low cost and high speed alternative to other fabricating methods, such as poly dimethyl siloxane (PDMS) casting [48]. The electron beam lithography combined with injection molding method allows one to fabricate a large number of identical surfaces in a short time and at low cost. In comparison to other studies, often performed using few samples (typically with sample size of three) to investigate the different nano-patterned features [49-51], we used a larger sample size than the optimal sample size $(n=186$, calculated by power analysis). When studying nano-patterned feature surface effects on bacteria, it is therefore important to always have the appropriate sample size. Unfortunately, when studying bacteria, optimal sample size is larger and it may be difficult to produce nano-patterned feature surfaces in large enough quantities.

The findings in the present study show that all strains investigated were affected by the presence of nanopillars on the surface. Although type 1 fimbriae is an important virulence factor for medical device infections, and expression is associated with increased biofilm formation and catheter-associated urinary tract infections [15,17,18,26,52,53], we observed reduced adhesion of the wild type E. coli compared to deletion mutants for the type 1 fimbriae monomers fimA or fimH for surfaces with nanopillars.

Our experimental findings showed an overall hydrophilic nature of the tested surfaces. Due to the size of the surfaces $(1 \times 3 \mathrm{~mm})$, separate surface angle measurements for the different surfaces coverages were not performed. The hydrophilicity of surfaces has been described to affect bacterial adhesion. Otto et al. [54] used microscope slides in order to obtain hydrophilic (contact angle determined as $<10^{\circ}$ ) and hydrophobic (contact angle determined as $>85^{\circ}$ ) surfaces. They found that the expression of type 1 fimbriae by E. coli reduced initial adhesion compared to mutants not expressing fimbriae, in accordance with the present findings. In addition, the authors reported increased adhesion strength for $E$. coli expressing type 1 fimbriae to hydrophobic surfaces compared to hydrophilic surfaces, whereas no difference was observed for the E. coli not expressing type 1 fimbriae.

Several studies have shown that adhesion of E. coli is affected by changes in surface topography. Widyaratih et al. [55] used electron beam induced deposition (EBID) in order to create silicon surfaces with four different nanopattern types. Their surfaces resembled osteogenic nanopatterns, and the adhesion of the E. coli K-12 strain was investigated. Topographies with tall nanopillars (over $100 \mathrm{~nm}$ ) showed bactericidal effects and changes in the physiological morphology of cells. Among the changes were structure deformations and lack of ability to divide. For surfaces with nanopillars with lower heights (15-20 nm), comparable to the present study, a reduced adhesion was suggested compared to non-patterned surfaces, and no changes in morphology were observed (bacteria kept their rod shape). Another study by Bandara et al. [56] showed how natural nanotopography of dragonfly wing would affect adhesion of E. coli (NCTC 10418). Dragonfly wings are covered with nanopillars consisting of two populations with different heights, namely $189 \pm 67 \mathrm{~nm}$ and $311 \pm 52 \mathrm{~nm}$, respectively. The presence of nanopillars led to damage of bacterial membrane as a result of strong adhesion between nanopillars and extracellular polymeric substances (EPS) from bacteria, as well as shear force which appeared during bacterial attempts to move on the nanopillars. In comparison, the nanopillars were approximately 4.7 and 7.5 times higher than the nanopillars in the present study. However, the height of the nanopillars is not the only factor affecting bacterial adhesion and survival on surfaces. Hasan et al. [57] fabricated surfaces inspired by the dragonfly wings based on deep reactive ion etching of a silicon wafer. The surfaces were highly hydrophobic with nanopillars of $4 \mathrm{~nm}$ height and $220 \mathrm{~nm}$ in diameter that exerted bactericidal activity against both E. coli and Staphylococcus aureus. 
In addition to the morphology of the nanopillars on the surfaces, the density of the nanopillars has been shown to affect both adhesive and bactericidal properties of surfaces. Dickson et al. [58] showed that by increasing the density of nanopillars on the surfaces of poly (methyl methacrylate) (PMMA) films, an increase in the bactericidal activity and decreased adhesion of E. coli was observed. The present study investigated surfaces with interspace distances varying between 100 and $500 \mathrm{~nm}$. The higher the distance, the lower number of pillars that bacteria may adhere to. Depending on the cell size, the highest interspace distance would allow a single E. coli cell to establish contact with only one to four pillars. In contrast to the study by Dickson et al. [58], we observed increased initial adhesion to the surfaces with higher nanopillar density. This observation may be explained by, for example, a different contact time used to investigate adhesion and difference in chemistry of the surfaces

\section{Conclusions}

We have presented a method of producing a large number of identical nanostructured surfaces. E. coli wild type and deletion mutants of the type 1 fimbriae monomers FimA or FimH were tested for their ability to adhere to such surfaces with different interpillar distance of 100, 250, and $500 \mathrm{~nm}$, respectively. An increase in interpillar distance (reduced surface coverage) was associated with reduced adhesion of E. coli wild type and the deletion mutants. In addition, the presence of a functional type 1 fimbria decreased adhesion to the nanopatterned surfaces in comparison to deletion mutants, leading us to the conclusion that there is a relationship between presence of a functional fimbriae and adhesion towards tested surfaces. The hypothesis that the presence of fimbriae had an effect on bacterial attachment to nanostructured surfaces was verified. These current results could provide insight into development of new nano-patterned structures with anti-adhesion bacterial properties.

Author Contributions: Conceptualization, H.J.H., H.V., and N.G. methodology, M.H., H.J.H, H.V., and N.G.; formal analysis, data curation investigation P.K. and J.S.-D.; writing-original draft preparation, PK and H.V.; writing-review and editing, M.A., M.H., H.J.H., H.V., and N.G.; supervision, M.A., P.K. and H.V.; project administration, P.K. and H.V. All authors have read and agreed to the published version of the manuscript

Funding: This research received no external funding

Acknowledgments: Antje Hofgaard at the Department of Biosciences, $\mathrm{UiO}$, is acknowledged for her help and expertise in SEM measurements.

Conflicts of Interest: The authors declare no conflict of interest

\section{References}

1. Khan, H.A.; Baig, F.K.; Mehboob, R. Nosocomial infections: Epidemiology, prevention, control and surveillance. Asian. Pac. J. Trop. Bio. 2017, 7, 478-482. [CrossRef]

2. Inweregbu, K.; Dave, J.; Pittard, A. Nosocomial infections. Cont. Care Pain 2005, 5, 14-17. [CrossRef]

3. Darouiche, R.O. Device-associated infections: A macroproblem that starts with microadherence. Clin. Infect. Dis. 2001, 33, 1567-1572. [CrossRef] [PubMed]

4. Afle, F.C.D.; Agbankpe, A.J.; Johnson, R.C.; Houngbegnon, O.; Houssou, S.C.; Bankole, H.S. Healthcare-associated infections: Bacteriological characterization of the hospital surfaces in the University Hospital of Abomey-Calavi/so-ava in South Benin (West Africa). BMC. Infect. Dis. 2019, 19, 28. [CrossRef] [PubMed]

5. Öztürk, R.; Murt, A. Epidemiology of urological infections: A global burden. World J. of Uro. 2020. [CrossRef]

6. Friedman, C.; Newsom, W. IFIC Basic Concepts of Infection Control; International Federation of Infection Control: Portadown, UK, 2011; p. 259.

7. Campbell, N.A.; Reece, J.B. Biology: International Edition, 6th ed.; Pearson Education, Inc.: London, UK, 2002; pp. 595-615, 6th ed.

8. Salyers, A.A.; Whitt, D.D.; Whitt, D.D. Bacterial Pathogenesis: A Molecular Approach, 1st ed.; ASM Press: Washington, DC, USA, 1994; p. 190, 1st ed.

9. Stecher, B.; Hardt, W.D. The role of microbiota in infectious disease. Trends Microbiol. 2008, 16, $107-114$. [CrossRef] [PubMed] 
10. Johnson, J.R.; Moseley, S.L.; Roberts, P.L.; Stamm, W.E. Aerobactin and other virulence factor genes among strains of Escherichia coli causing urosepsis: Association with patient characteristics. Infect. Immun. 1988, 56, 405-412. [CrossRef] [PubMed]

11. Martinez, J.J.; Mulvey, M.A.; Schilling, J.D.; Pinkner, J.S.; Hultgren, S.J. Type 1 pilus-mediated bacterial invasion of bladder epithelial cells. EMBO. J. 2000, 19, 2803-2812. [CrossRef]

12. Klemm, P.; Krogfelt, K.A.; Hedegaard, L.; Christiansen, G. The major subunit of Escherichia coli type 1 fimbriae is not required for D-mannose-specific adhesion. Mol. Microbiol. 1990, 4, 553-559. [CrossRef]

13. Russell, P.W.; Orndorff, P.E. Lesions in two Escherichia coli type 1 pilus genes alter pilus number and length without affecting receptor binding. J. Bacteriol. 1992, 174, 5923-5935. [CrossRef]

14. Jones, C.H.; Pinkner, J.S.; Roth, R.; Heuser, J.; Nicholes, A.V.; Abraham, S.N.; Hultgren, S.J. FimH adhesin of type 1 pili is assembled into a fibrillar tip structure in the Enterobacteriaceae. Proc. Natl. Acad. Sci. USA 1995, 92, 2081-2085. [CrossRef] [PubMed]

15. Blumer, C.; Kleefeld, A.; Lehnen, D.; Heintz, M.; Dobrindt, U.; Nagy, G.; Michaelis, K.; Emödy, L.; Polen, T.; Rachel, R.; et al. Regulation of type 1 fimbriae synthesis and biofilm formation by the transcriptional regulator LrhA of Escherichia coli. Microbiology (Reading) 2005, 151, 3287-3298. [CrossRef] [PubMed]

16. Reisner, A.; Maierl, M.; Jorger, M.; Krause, R.; Berger, D.; Haid, A.; Tesic, D.; Zechner, E.L. Type 1 fimbriae contribute to catheter-associated urinary tract infections caused by Escherichia coli. J. Bacteriol. 2014, 196, 931-939. [CrossRef] [PubMed]

17. Donlan, R.M. Biofilms and device-associated infections. Emerg. Infect. Dis. 2001, 7, 277-281. [CrossRef] [PubMed]

18. Valen, H.; Scheie, A.A. Biofilms and their properties. Eur. J. Oral Sci. 2018, 126, 13-18. [CrossRef]

19. Kalivoda, E.J.; Stella, N.A.; O’Dee, D.M.; Nau, G.J.; Shanks, R.M. The cyclic AMP-dependent catabolite repression system of Serratia marcescens mediates biofilm formation through regulation of type 1 fimbriae. Appl. Environ. Microbiol. 2008, 74, 3461-3470. [CrossRef]

20. Stahlhut, S.G.; Struve, C.; Krogfelt, K.A.; Reisner, A. Biofilm formation of Klebsiella pneumoniae on urethral catheters requires either type 1 or type 3 fimbriae. FEMS Immunol. Med. Microbiol. 2012, 65, 350-359. [CrossRef]

21. Platt, R.; Polk, B.F.; Murdock, B.; Rosner, B. Mortality associated with nosocomial urinary-tract infection. N. Engl. J. Med. 1982, 307, 637-642. [CrossRef]

22. Lee, D.S.; Lee, S.J.; Choe, H.S. Community-Acquired Urinary Tract Infection by Escherichia coli in the Era of Antibiotic Resistance. Biomed. Res. Int. 2018, 2018, 7656752. [CrossRef]

23. Alanazi, M.Q.; Alqahtani, F.Y.; Aleanizy, F.S. An evaluation of E. coli in urinary tract infection in emergency department at KAMC in Riyadh, Saudi Arabia: Retrospective study. Ann. Clin. Microbiol. Antimicrob. 2018, 17, 3. [CrossRef]

24. Garofalo, C.K.; Hooton, T.M.; Martin, S.M.; Stamm, W.E.; Palermo, J.J.; Gordon, J.I.; Hultgren, S.J. Escherichia coli from urine of female patients with urinary tract infections is competent for intracellular bacterial community formation. Infect Immun. 2007, 75, 52-60. [CrossRef] [PubMed]

25. Marrs, C.F.; Zhang, L.; Foxman, B. Escherichia coli mediated urinary tract infections: Are there distinct uropathogenic E. coli (UPEC) pathotypes? FEMS Microbiol. Lett. 2005, 252, 183-190. [CrossRef] [PubMed]

26. Connell, I.; Agace, W.; Klemm, P.; Schembri, M.; Marild, S.; Svanborg, C. Type 1 fimbrial expression enhances Escherichia coli virulence for the urinary tract. Proc. Natl. Acad. Sci. USA 1996, 93, 9827-9832. [CrossRef] [PubMed]

27. Mozetic, M. Surface Modification to Improve Properties of Materials. Materials (Basel) 2019, 12, 441. [CrossRef]

28. Rahmati, M.; Silva, E.A.; Reseland, J.E.; C, A.H.; Haugen, H.J. Biological responses to physicochemical properties of biomaterial surface. Chem. Soc. Rev. 2020, 49, 5178-5224. [CrossRef]

29. Tripathy, A.; Sen, P.; Su, B.; Briscoe, W.H. Natural and bioinspired nanostructured bactericidal surfaces. Adv. Colloid Interface Sci. 2017, 248, 85-104. [CrossRef]

30. Øilo, M.; Bakken, V. Biofilm and Dental Biomaterials. Materials 2015, 8, 2887-2900. [CrossRef]

31. Wang, L.; Hu, C.; Shao, L. The antimicrobial activity of nanoparticles: Present situation and prospects for the future. Int. J. Nanomed. 2017, 12, 1227-1249. [CrossRef]

32. Xing, R.; Lyngstadaas, S.P.; Ellingsen, J.E.; Taxt-Lamolle, S.; Haugen, H.J. The influence of surface nanoroughness, texture and chemistry of TiZr implant abutment on oral biofilm accumulation. Clin. Oral Implants Res. 2015, 26, 649-656. [CrossRef] 
33. Haugen, H.; Lyngstadaas, S. Antibacterial effects of titanium dioxide in wounds. In Wound Healing Biomaterials-Volume 2: Functional Biomaterials; Ågren, M.S., Ed.; Elsevier: Amsterdam, The Netherlands, 2016; p. 439.

34. Dhull, N.; Nidhi; Gupta, V.; Tomar, M. Antimicrobial properties of metallic nanoparticles: A qualitative analysis. Mater. Today: Proc. 2019, 17, 155-160. [CrossRef]

35. Smirnov, N.A.; Kudryashov, S.I.; Nastulyavichus, A.A.; Rudenko, A.A.; Saraeva, I.N.; Tolordava, E.R.; Gonchukov, S.A.; Romanova, Y.M.; Ionin, A.A.; Zayarny, D.A. Antibacterial properties of silicon nanoparticles. Laser Phys. Lett. 2018, 15, 105602. [CrossRef]

36. Asefa, T.; Tao, Z. Biocompatibility of mesoporous silica nanoparticles. Chem. Res. Toxicol. 2012, 25, 2265-2284. [CrossRef] [PubMed]

37. Sviridov, A.P.; Osminkina, L.A.; Kharin, A.Y.; Gongalsky, M.B.; Kargina, J.V.; Kudryavtsev, A.A.; Bezsudnova, Y.I.; Perova, T.S.; Geloen, A.; Lysenko, V.; et al. Cytotoxicity control of silicon nanoparticles by biopolymer coating and ultrasound irradiation for cancer theranostic applications. Nanotechnology 2017, 28, 105102. [CrossRef] [PubMed]

38. Tamarov, K.P.; Osminkina, L.A.; Zinovyev, S.V.; Maximova, K.A.; Kargina, J.V.; Gongalsky, M.B.; Ryabchikov, Y.; Al-Kattan, A.; Sviridov, A.P.; Sentis, M.; et al. Radio frequency radiation-induced hyperthermia using Si nanoparticle-based sensitizers for mild cancer therapy. Sci. Rep. 2014, 4, 7034. [CrossRef]

39. Charitidis, C.A.; Georgiou, P.; Koklioti, M.A.; Trompeta, A.-F.; Markakis, V. Manufacturing nanomaterials: From research to industry. Manufacturing Rev. 2014, 1, 11. [CrossRef]

40. Altissimo, M. E-beam lithography for micro-nanofabrication. Biomicrofluidics 2010, 4, 026503. [CrossRef]

41. Stormonth-Darling, J.M.; Gadegaard, N. Injection Moulding Difficult Nanopatterns with Hybrid Polymer Inlays. Macromol. Mater. Eng. 2012, 297, 1075-1080. [CrossRef]

42. Chao, Y.; Zhang, T. Probing Roles of Lipopolysaccharide, Type 1 Fimbria, and Colanic Acid in the Attachment of Escherichia coli Strains on Inert Surfaces. Langmuir 2011, 27, 11545-11553. [CrossRef]

43. Lönn-Stensrud, J.; Benneche, T.; Scheie, A.A. Furanones and Thiophenones in Control of Staphylococcus epidermidis Biofilm Infections? In Science and Technology Against Microbial Pathogens; World Scientific, Toh Tunk Link: Singapore, 2011; pp. 155-159. [CrossRef]

44. Hulander, M.; Valen-Rukke, H.; Sundell, G.; Andersson, M. Influence of Fibrinogen on Staphylococcus epidermidis Adhesion Can Be Reversed by Tuning Surface Nanotopography. ACS Biomater. Sci. Eng. 2019, 5, 4323-4330. [CrossRef]

45. Faul, F.; Erdfelder, E.; Lang, A.G.; Buchner, A. G*Power 3: A flexible statistical power analysis program for the social, behavioral, and biomedical sciences. Behav. Res. Methods 2007, 39, 175-191. [CrossRef]

46. Faul, F.; Erdfelder, E.; Buchner, A.; Lang, A.G. Statistical power analyses using G*Power 3.1: Tests for correlation and regression analyses. Behav. Res. Methods 2009, 41, 1149-1160. [CrossRef] [PubMed]

47. Stormonth-Darling, J.M.; Pedersen, R.H.; How, C.; Gadegaard, N. Injection moulding of ultra high aspect ratio nanostructures using coated polymer tooling. J. Micromech. Microeng. 2014, 24, 12. [CrossRef]

48. Darling, J.M.; Saeed, A.; Reynolds, P.M.; Gadegaard, N. Injection Molding Micro- and Nanostructures in Thermoplastic Elastomers. Macromol. Mater. Eng. 2016, 301, 964-971. [CrossRef] [PubMed]

49. Yu, Q.; Cho, J.; Shivapooja, P.; Ista, L.K.; Lopez, G.P. Nanopatterned smart polymer surfaces for controlled attachment, killing, and release of bacteria. ACS Appl. Mater. Interfaces 2013, 5, 9295-9304. [CrossRef] [PubMed]

50. Liu, L.T.; Ercan, B.; Sun, L.L.; Ziemer, K.S.; Webster, T.J. Understanding the Role of Polymer Surface Nanoscale Topography on Inhibiting Bacteria Adhesion and Growth. ACS Biomater Sci. Eng. 2016, 2, 122-130. [CrossRef]

51. Linklater, D.P.; Baulin, V.A.; Juodkazis, S.; Crawford, R.J.; Stoodley, P.; Ivanova, E.P. Mechano-bactericidal actions of nanostructured surfaces. Nat. Rev. Microbiol 2020, 1-15, Epub ahead of print. [CrossRef] [PubMed]

52. Melican, K.; Sandoval, R.M.; Kader, A.; Josefsson, L.; Tanner, G.A.; Molitoris, B.A.; Richter-Dahlfors, A. Uropathogenic Escherichia coli $\mathrm{P}$ and Type 1 fimbriae act in synergy in a living host to facilitate renal colonization leading to nephron obstruction. PLoS. Pathog. 2011, 7, e1001298. [CrossRef]

53. Klemm, P. Fimbrial adhesions of Escherichia coli. Rev. Infect. Dis. 1985, 7, 321-340. [CrossRef]

54. Otto, K.; Elwing, H.; Hermansson, M. The role of type 1 fimbriae in adhesion of Escherichia coli to hydrophilic and hydrophobic surfaces. Colloids Surf. B-Biointerfaces 1999, 15, 99-111. [CrossRef] 
55. Widyaratih, D.S.; Hagedoorn, P.L.; Otten, L.G.; Ganjian, M.; Tumer, N.; Apachitei, I.; Hagen, C.W.; Fratila-Apachitei, L.E.; Zadpoor, A.A. Towards osteogenic and bactericidal nanopatterns? Nanotechnology 2019, 30, 20LT01. [CrossRef]

56. Bandara, C.D.; Singh, S.; Afara, I.O.; Wolff, A.; Tesfamichael, T.; Ostrikov, K.; Oloyede, A. Bactericidal Effects of Natural Nanotopography of Dragonfly Wing on Escherichia coli. ACS Appl. Mater. Interfaces 2017, 9, 6746-6760. [CrossRef] [PubMed]

57. Hasan, J.; Raj, S.; Yadav, L.; Chatterjee, K. Engineering a nanostructured "super surface" with superhydrophobic and superkilling properties. RSC Adv. 2015, 5, 44953-44959. [CrossRef] [PubMed]

58. Dickson, M.N.; Liang, E.I.; Rodriguez, L.A.; Vollereaux, N.; Yee, A.F. Nanopatterned polymer surfaces with bactericidal properties. Biointerphases 2015, 10, 021010. [CrossRef] [PubMed]

Publisher's Note: MDPI stays neutral with regard to jurisdictional claims in published maps and institutional affiliations.

(C) 2020 by the authors. Licensee MDPI, Basel, Switzerland. This article is an open access article distributed under the terms and conditions of the Creative Commons Attribution (CC BY) license (http://creativecommons.org/licenses/by/4.0/). 